\title{
Instytucja referendum w Republice Tatarstanu (Federacja Rosyjska)
}

W myśl Konstytucji Federacji Rosyjskiej (KFR) z 1993 roku Rosja² jest państwem federacyjnym (art. 1 KFR) składającym się z republik, krajów, obwodów, miast o znaczeniu federalnym, obwodów autonomicznych i okręgów autonomicznych (art. 5 ust. 1 KFR). Jakkolwiek wymienione podmioty są traktowane jako wzajemnie równorzędne, to jednak można dostrzec prymat republik wśród wszystkich podmiotów wchodzących w skład Federacji. Wynika to z art. 5 ust. 2 KFR, który stanowi, że republiki posiadają własne konstytucje i ustawodawstwo, podczas gdy pozostałe części składowe Federacji mogą posiadać własne statuty i ustawodawstwo ${ }^{3}$. Należy jednocześnie podkreślić, że konstytucje poszczególnych republik są częścią systemu prawnego na terytorium Rosji pod warunkiem przyjęcia zasady nadrzędności KFR oraz niewystępowania sprzeczności z KFR. W związku z powyższym konstytucje republik nie mają samoistnej mocy prawnej oraz są podrzędne wobec KFR.

W art. 65 KFR wymieniono wszystkie podmioty wchodzące w skład Federacji Rosyjskiej. Wśród 22 republik ${ }^{4}$ znajduje się Republika Tatarstanu (RT lub zamiennie Ta-

1 Artykuł przygotowano $\mathrm{w}$ ramach projektu badawczego $\mathrm{nr}$ 2014/15/B/HS5/01866 finansowanego przez Narodowe Centrum Nauki.

2 Zgodnie z art. 1 ust. 2 KFR nazwy Federacja Rosyjska i Rosja są równoznaczne.

3 Na tę zależność zwrócił uwagę także Eugeniusz Zieliński, który odwołał się do historycznego i kulturowego wymiaru, stwierdzając, że republiki „wykształcone w przeszłości i tworzące wspólne więzi społeczności wyróżniły się odrębnością kulturową. Ich autonomia terytorialna stanowiła podstawę dążeń do samodzielności państwowej. Stąd tendencja do zachowania pewnej odrębności i autonomii w ramach wielonarodowej wspólnoty państwowej”. E. Zieliński, System konstytucyjny Federacji Rosyjskiej, Warszawa 2005, s. 43.

4 Na liczbę dwudziestu dwóch republik złożyło się dwadzieścia jeden republik wpisanych do KFR w 1993 roku (w czterech przypadkach dokonano zmiany nazw republik w latach 1996 i 2001) oraz Republika Krymu włączona w skład Federacji Rosyjskiej na podstawie federalnej ustawy konstytucyjnej z 21 marca 2017 roku N 6-FKZ O przyjęciu Republiki Krymu w skład Federacji Rosyjskiej i włączeniu w skład Federacji Rosyjskiej nowych podmiotów: Republiki Krymu i Sewastopola, 
$\left.\operatorname{tarstan}^{5}\right)$. Republika ta jest jedną z niewielu podmiotów Federacji, które po rozpadzie Związku Radzieckiego odwołały się do instytucji referendum na poziomie republiki w celu zdefiniowania statusu republiki ${ }^{6}$.

W związku z powyższym niniejszemu artykułowi przyświecały następujące cele: określenie statusu instytucji referendum w rosyjskim (federalnym) i tatarskim (republikańskim) systemie prawnym oraz dokonanie analizy przykładów zastosowania instytucji referendum w RT na poziomach republiki oraz lokalnym.

\section{Instytucja referendum w rosyjskim i tatarskim systemach prawnych}

Na system prawny Federacji Rosyjskiej oraz Republiki Tatarstanu składają się konstytucje, federalne ustawy konstytucyjne, ustawy federalne oraz ustawy. Należy podkreślić specyfikę systemu ustaw, ponieważ pomimo występowania kilku aktów prawnych w zakresie instytucji referendum zarówno na poziomie federalnym, jak i lokalnym treści poszczególnych ustaw są wzajemnie tożsame, a różnica dotyczy jedynie numeracji artykułów lub zakresu przedmiotowego. W związku z powyższym poniżej szerzej przedstawiono jedną ustawę jako egzemplifikację charakterystyczną dla danego poziomu.

W art. 3 ust. 1 i 2 KFR wprowadzono zasadę zwierzchnictwa ludu, polegającą na tym, że obywatele mogą sprawować władzę w sposób bezpośredni lub pośredni. Przykładem pierwszego rozwiązania w myśl art. 3 ust. 3 jest referendum, natomiast drugiego - wolne wybory. Ponownie nawiązano do instytucji referendum w rozdziale II „Prawa i wolności człowieka i obywateli”, w którym wymieniono katalog praw i wolności. W art. 32 ust. 1 KFR stwierdzono, że obywatele Rosji mają prawo do udziału w kierowaniu sprawami państwa w sposób bezpośredni (jak i pośredni), natomiast w art. 32 ust. 2 KFR doprecyzowano, że prawo to obejmuje udział obywateli w referendum. Powtórnie do instytucji referendum nawiązano w rozdziale IV „Prezydent Federacji Rosyjskiej”, w którym w art. 84 KFR stwierdzono, że referendum jest zarządzane przez głowę państwa $\mathrm{w}$ trybie określonym przez federalną ustawę konstytucyjną. Jednocześnie w art. 92 KFR uregulowano sytuację negatywną, ponieważ zakazano prawa do zarządzenia referendum przez Przewodniczącego Rządu Federacji Rosyjskiej (premiera rządu), gdy zastępuje on Prezydenta Federacji Rosyjskiej.

miasta o znaczeniu federalnym. Należy podkreślić jednostronność podjętych działań przez Federację Rosyjską, ponieważ w art. 133 Konstytucji Ukrainy (KU) wymieniono podmioty wchodzące w skład państwa. Znalazły się wśród nich zarówno Sewastopol jako miasto o specjalnym statusie, jak i Autonomiczna Republika Krymu. Unitarność państwa wzmocniono w art. 134 KU, w którym stwierdzono, że „Autonomiczna Republika Krymu jest nieodłączną częścią składową Ukrainy”. Nie miało to jednak znaczenia dla władz Federacji Rosyjskiej, które legitymizują swoją politykę w akcie wyborczym, odwołując się do wyników referendów z 17 marca 2014 roku.

5 Zgodnie z art. 1 ust. 2 KRT nazwy Republika Tatarstanu i Tatarstan są równoznaczne.

6 Referenda na poziomie republik odbywały się w: Republice Czeczenii w latach 2003 i 2007, Republice Kabardyjsko-Bałkarskiej w latach 1991 i 1994 oraz Republice Tuwy w latach 1993, 2001 i 2010, http://www.c2d.ch inf. 29 VI 2017. 
W rozdziale VIII „Samorząd lokalny” nawiązano do instytucji referendum w kontekście przepisów dotyczących samorządu terytorialnego. Stwierdzono, że samorządność terytorialna jest realizowana przez obywateli w drodze referendum (wyborów) i innych form wyrażania woli (art. 130 ust. $2 \mathrm{KFR})^{7}$. Instytucja referendum została włączona do trybu uchwalenia nowej konstytucji Federacji Rosyjskiej (art. 135 KFR). Projekt zmiany ustawy zasadniczej zostaje przyjęty, gdy w referendum weźmie udział więcej niż połowa obywateli uprawnionych do głosowania, a za projektem zagłosuje więcej niż połowa uczestniczących.

Tabela 1. Zestawienie artykułów Konstytucji Federacji Rosyjskiej z 1993 roku i Konstytucji Republiki Tatarstanu z 1992 roku w sprawie instytucji referendum

\begin{tabular}{|l|l|l|l|l|l|l|}
\hline $\begin{array}{l}\text { Federacja } \\
\text { Rosyjska }\end{array}$ & $\begin{array}{l}\text { Art. 3 } \\
\text { Lud } \\
\text { sprawuje } \\
\text { władzę bez- } \\
\text { pośrednio } \\
\text { w referen- } \\
\text { dum }\end{array}$ & $\begin{array}{l}\text { Art. 32 } \\
\text { Obywatele } \\
\text { uczestniczą } \\
\text { w sposób } \\
\text { bezpośredni } \\
\text { poprzez } \\
\text { referendum }\end{array}$ & $\begin{array}{l}\text { Art. 84 } \\
\text { Prezydent } \\
\text { Federacji } \\
\text { Rosyjskiej } \\
\text { zarządza } \\
\text { referendum }\end{array}$ & $\begin{array}{l}\text { Art. 92 } \\
\text { Premier } \\
\text { w okresie } \\
\text { zastępo- } \\
\text { wania } \\
\text { Prezydenta } \\
\text { nie można } \\
\text { zarządzić re- } \\
\text { ferendum }\end{array}$ & $\begin{array}{l}\text { Art. 130 } \\
\text { Samorząd- } \\
\text { ność lokalna } \\
\text { realizowana } \\
\text { jest przez } \\
\text { obywateli } \\
\text { poprzez } \\
\text { referendum }\end{array}$ & $\begin{array}{l}\text { Art. 135 } \\
\text { Projekt nowej } \\
\text { konstytucji } \\
\text { może być } \\
\text { procedowany } \\
\text { w głosowaniu } \\
\text { referendalnym }\end{array}$ \\
\hline $\begin{array}{l}\text { Republika } \\
\text { Tatarstanu }\end{array}$ & $\begin{array}{l}\text { Art. 3 } \\
\text { Lud } \\
\text { sprawuje } \\
\text { władzę bez- } \\
\text { pośrednio } \\
\text { w referen- } \\
\text { dum }\end{array}$ & $\begin{array}{l}\text { Art. 45 } \\
\text { Obywatele } \\
\text { uczestniczą } \\
\text { w sposób } \\
\text { bezpośredni } \\
\text { poprzez } \\
\text { referendum }\end{array}$ & $\begin{array}{l}\text { Art. 75 } \\
\text { Rada } \\
\text { Państwa } \\
\text { Republiki } \\
\text { Tatarstanu } \\
\text { Zarządza } \\
\text { referendum }\end{array}$ & $\begin{array}{l}\text { Art. 116 } \\
\text { Premier } \\
\text { w okresie } \\
\text { zastępo- } \\
\text { wania } \\
\text { Prezydenta } \\
\text { nie można } \\
\text { inicjować } \\
\text { referendum }\end{array}$ & $\begin{array}{l}\text { Art. 116 } \\
\text { Samorząd- } \\
\text { ność lokalna } \\
\text { realizowana } \\
\text { jest przez } \\
\text { obywateli } \\
\text { poprzez } \\
\text { referendum }\end{array}$ & $\begin{array}{l}\text { Art. 123 } \\
\text { Zmiana art. 1 } \\
\text { oraz art. 123 } \\
\text { Konstytucji Ta- } \\
\text { tarstanu tylko } \\
\text { w głosowaniu } \\
\text { referendalnym }\end{array}$ \\
\hline
\end{tabular}

Źródło: Opracowanie własne na podstawie Konstytucji Federacji Rosyjskiej z 1993 roku oraz Konstytucji Republiki Tatarstanu z 1992 roku, http://constitution.garant.ru; http://constitution. garant.ru/region/cons_tatar/, inf. 29 VI 2017 oraz 19 VII 2017.

W związku z zasadą nadrzędności KFR względem Konstytucji Republiki Tatarstanu (KRT) z 6 listopada 1992 roku (z późn. zm.) i niewystępowaniem sprzeczności można wykazać tożsamość przepisów KFR i KRT w zakresie instytucji referendum. W art. 3 ust. 3 KRT stwierdzono, że najwyższym wyrazem władzy bezpośredniej sprawowanej przez lud jest referendum. Na podkreślenie zasługuje umieszczenie powyższego artykułu w rozdziale I „Podstawy ustroju konstytucyjnego”, który posiada tożsamy tytuł z roz-

7 Eugeniusz Zieliński podsumował, że „system samorządu terytorialnego tworzą regiony wiejskie i miejskie oraz rejony dzielnic miast, a także wsie i osiedla oraz małe miasta. Na system ten składają się zgromadzenia mieszkańców, zebrania przedstawicieli mieszkańców, wybieralne organy przedstawicielskie i organy wykonawcze decydujące o sprawach lokalnych. Samorządność przejawia się także w udziale mieszkańców w referendach i wyborach powszechnych przedstawicieli do ciał wybieralnych". E. Zieliński, op. cit., s. 90. 
działem I KFR. Podobnie w przypadku art. 45 ust. 1 i 2 KRT, który nawiązuje do prawa obywateli do udziału w życiu politycznym i społecznym w sposób bezpośredni (lub pośredni). Przykładem takiego rozwiązania jest prawo do udziału w referendum. Powyższy artykuł jest analogiczny w stosunku do art. 32 KFR. Oba artykuły umieszczono w rozdziałach II dotyczących praw i wolności człowieka i obywatela. W art. 75 pkt. 14 KRT wymieniono kompetencje Rady Państwa RT (100-osobowego parlamentu RT), wśród których wymieniono m.in. zarządzanie referendum. Na poziomie federalnym prawo to przysługuje Prezydentowi Federacji Rosyjskiej. Jednocześnie w art. 98 ust. 2 KRT wskazano, że w przypadku zastępstwa Prezydenta Republiki Tatarstanu przez Premiera Rady Ministrów Republiki Tatarstanu nie może on inicjować procesu legislacyjnego w sprawie referendum (co jednocześnie oznacza, że Prezydent RT takie uprawnienie posiada, jednak nie zostało ono wyliczone w KRT). Art. 116 KRT jest tożsamy względem art. 130 KFR i dotyczy samorządności, która jest realizowana przez obywateli m.in. w trybie referendalnym. W art. $123 \mathrm{KRT}$ stwierdzono, że treść niniejszego artykułu oraz art. 1 KRT (dotyczącego statusu RT w ramach Federacji Rosyjskiej, w tym prawa do prowadzenia niezależnej polityki gospodarczej) nie mogą być zmienione w inny sposób, aniżeli w trybie referendum. Jednocześnie $\mathrm{w}$ trybie zmian do KRT 12 marca 2004 roku $^{8}$ wprowadzono art. $124 \mathrm{KRT}$, w których doprecyzowano, że zmiany konstytucyjne wprowadzone w trybie głosowania referendalnego są wiążące, jeśli wzięła w nim udział co najmniej połowa obywateli uprawnionych do głosowania. Zestawienie obu aktów prawnych (patrz tabela 1) potwierdza dużą zbieżność przepisów prawnych w zakresie referendum. Do różnic należy zaliczyć przyznanie prawa do zarządzania referendum Prezydentowi Federacji Rosyjskiej na podstawie przepisów KFR oraz Radzie Państwa Republiki Tatarstanu w KRT. Ponadto można wskazać, że instytucja referendum została włączona do trybu zmiany konstytucji. W przypadku KFR Zgromadzenie Konstytucyjne podejmuje decyzje o wyborze trybu, natomiast w KRT wymieniono dwa artykuły (1 i 123), których zmiana może być przeprowadzona tylko w trybie referendalnym.

Uszczegółowieniem instytucji referendum na poziomie ustawowym jest Federalna ustawa konstytucyjna $O$ referendum w Federacji Rosyjskiej (RFR) z 11 czerwca 2004 roku' ${ }^{9}$ która doprecyzowuje sytuacje, w których tryb referendalny nie może zostać zastosowany (ujęcie negatywne). Zgodnie z art. 6 RFR głosowanie referendalne nie może dotyczyć: zmiany statusu podmiotów Federacji Rosyjskiej, skrócenia lub przedłużenia kadencji Prezydenta Federacji Rosyjskiej, Dumy Państwowej, Rady Federacji oraz przedterminowych lub odroczonych wyborów do wyżej wymienionych organów, wyboru osób pełniących funkcje publiczne w Federacji Rosyjskiej, wyboru osób uczestniczących we władzach federalnych lub federalnych agencjach rządowych, wyboru osób powoływanych na stanowisko w wyniku przyjęcia przez Federację Rosyjską porozu-

\footnotetext{
Закон Республики Татарстан о внесении изменений и дополнений в отдельные статьи Конституции Республики Татарстан, 12 марта 2004 года, N 10-3РТ.

9 Федералный Конституционный Закон Российской Федерации о референдуме Российской Федерации, 28 июня 2004 года, N5-ФКЗ.
} 
mień międzynarodowych, przyjęcia środków nadzwyczajnych w celu zapewnienia bezpieczeństwa i ochrony zdrowia publicznego.

Do podstawowych zasad zaliczono: powszechne, równe, bezpośrednie, tajne i wolne referendum (art. 2 RFR). Prawo do udziału w referendum posiadają obywatele Federacji Rosyjskiej, którzy ukończyli 18 lat. Powyższe prawo obejmuje obywateli Rosji zamieszkujących lub przebywających poza terytorium Federacji (art. 5 RFR). $\mathrm{W}$ art. 14 RFR stwierdzono, że prawo do inicjowania referendum należy do obywateli w liczbie nie mniejszej, aniżeli 2 miliony z zastrzeżeniem, że na obszarze jednego podmiotu Federacji lub łącznie poza granicami Federacji zamieszkuje nie więcej niż 50 tysięcy. Obywatele muszą złożyć podpisy poparcia pod wnioskiem o przeprowadzenie referendum w ciągu 45 dni od daty rejestracji Referendalnej Grupy Inicjatywnej (art. 17 RFR). Za organizowanie, przygotowanie i przeprowadzenie referendum oraz nadzorowanie prac komisji niższego stopnia odpowiedzialna jest Centralna Komisja Wyborcza (art. 30 RFR). Uzupełnieniem RFR jest ustawa federalna O podstawowych gwarancjach praw wyborczych oraz prawie do udziału w referendum obywateli Federacji Rosyjskiej z 12 czerwca 2002 roku $^{10}$. Część ogólna ustawy federalnej jest tożsama z RFR.

Tatarski system prawny obejmuje dwie ustawy referendalne: ustawę $O$ referendum w Republice Tatarstanu z 9 sierpnia 2003 roku (RRT) ${ }^{11}$ oraz ustawę O referendum lokalnym w Republice Tatarstanu z 23 marca 2004 roku (RL) ${ }^{12}$. W art. 3 RRT wymieniono zasady referendalne, do których zaliczono: głosowanie powszechne, równe, bezpośrednie, wolne i tajne. Do głosowania referendalnego uprawnieni są obywatele, którzy zamieszkują Republikę Tatarstanu i ukończyli 18. rok życia w dniu głosowania (art. 4 RRT). Zakres problemowy instytucji referendum został zdefiniowany w sposób pozytywny i negatywny (art. 9 RRT). W ustawie stwierdzono, że referendum może dotyczyć tylko kwestii pozostających w kompetencji organów władzy RT lub kompetencji wspólnych Tatarstanu i Federacji Rosyjskiej. Powtórzono art. 123 KRT, przypominając, że referendum ma charakter obligatoryjny w przypadku zmiany treści art. 1 i 123 KRT (art. 9 ust. 2 RRT). Jednocześnie w ustawie przyjęto, że referendum nie powinno ograniczać lub znosić konstytucyjnych praw i wolności człowieka i obywatela. Dodatkowo za ustawami federalnymi potwierdzono, że zakres problemowy referendum nie może obejmować: przedterminowego rozwiązania lub przedłużenia kadencji organów władzy publicznej RT; wyboru pracowników organów władz publicznych RT; wyboru deputowanych i urzędników, ich zatwierdzenia lub odwołania; przyjęcia lub zmiany budżetu lub polityki gospodarczej RT; zastosowania środków nadzwyczajnych w celu zapewnienia bezpieczeństwa i zdrowia publicznego. Organizacja referendum jest zakazana w okresie trwania lub po zniesieniu stanu wojennego w ciągu trzech miesięcy

10 Федеральный закон Российской Федерации об основных гарантиях избирательных прав и права на участие в референдуме граждан Российской Федерации, 12 июня 2002 года, N 67-Ф3.

11 Закон Республики Татарстан о референдуме Республики Татарстан, 9 августа 2003 года, N 33-3PT.

12 Закон Республики Татарстан о местном референдуме Республики Татарстан, 23 марта 2004 года, N 23-3РТ. 
albo stanu wyjątkowego obowiązującego na terytorium FR, RT lub części RT. Zgodnie $\mathrm{z}$ art. 13 RRT podpisy pod wnioskiem o przeprowadzenie referendum można zbierać przez 30 dni po zarejestrowaniu komitetu organizacyjnego. W celu procedowania referendum na poziomie republiki niezbędne jest zebranie co najmniej $2 \%$ podpisów wyborców zarejestrowanych w RT, natomiast w przypadku referendum lokalnego wniosek referendalny wymaga poparcia co najmniej $5 \%$ wyborców zamieszkujących daną jednostkę terytorialną, jednocześnie nie może to być mniej aniżeli 25 osób. Za przygotowanie i przeprowadzenie referendum jest odpowiedzialna Centralna Komisja Wyborcza Republiki Tatarstanu (art. 17 RRT). Zakres problemowy referendum lokalnego został ograniczony do kwestii lokalnych (art. $10 \mathrm{RL}$ ) nieobjętych regulacjami RRT.

Tabela 2. Zestawienie wybranych regulacji prawnych w rosyjskich i tatarskich ustawach w zakresie instytucji referendum

\begin{tabular}{|c|c|c|c|c|}
\hline \multirow{2}{*}{ Regulacje } & \multicolumn{2}{|c|}{ Poziom Federacji Rosyjskiej } & \multicolumn{2}{|c|}{ Poziom Republiki Tatarstanu } \\
\hline & RFR & PGP & RRT & $\mathrm{RL}$ \\
\hline $\begin{array}{l}\text { Zasady referen- } \\
\text { dalne }\end{array}$ & $\begin{array}{l}\text { Głosowanie po- } \\
\text { wszechne, równe, } \\
\text { bezpośrednie, tajne, } \\
\text { wolne }\end{array}$ & $\begin{array}{l}\text { Głosowanie po- } \\
\text { wszechne, równe, } \\
\text { bezpośrednie, } \\
\text { tajne, wolne }\end{array}$ & $\begin{array}{l}\text { Głosowanie po- } \\
\text { wszechne, równe, } \\
\text { bezpośrednie, tajne, } \\
\text { wolne }\end{array}$ & $\begin{array}{l}\text { Głosowanie po- } \\
\text { wszechne, równe, } \\
\text { bezpośrednie, } \\
\text { tajne, wolne }\end{array}$ \\
\hline $\begin{array}{l}\text { Uprawnieni do } \\
\text { głosowania }\end{array}$ & $\begin{array}{l}\text { Obywatele Rosji, } \\
\text { którzy ukończyli } 18 \\
\text { lat w dniu głoso- } \\
\text { wania }\end{array}$ & $\begin{array}{l}\text { Obywatele Rosji, } \\
\text { którzy ukończyli } \\
18 \text { lat w dniu } \\
\text { głosowania }\end{array}$ & $\begin{array}{l}\text { Obywatele zamiesz- } \\
\text { kujący Republikę } \\
\text { Tatarstanu, którzy } \\
\text { ukończyli } 18 \text { lat } \\
\text { w dniu głosowania }\end{array}$ & $\begin{array}{l}\text { Obywatele } \\
\text { zamieszkujący } \\
\text { jednostkę lokalną, } \\
\text { którzy ukończyli } \\
18 \text { lat w dniu } \\
\text { głosowania } \\
\end{array}$ \\
\hline $\begin{array}{l}\text { Liczba niezbęd- } \\
\text { nych podpisów } \\
\text { obywateli pod } \\
\text { wnioskiem o orga- } \\
\text { nizację referen- } \\
\text { dum }\end{array}$ & $\begin{array}{l}2 \text { miliony na } \\
\text { obszarze jednego } \\
\text { podmiotu Federacji } \\
\text { lub łącznie poza } \\
\text { granicami Federacji } \\
\text { zamieszkuje nie wię- } \\
\text { cej niż } 50 \text { tysięcy }\end{array}$ & - & $\begin{array}{l}\% \text { wyborców } \\
\text { zarejestrowanych } \\
\text { w Republice Tatar- } \\
\text { stanu }\end{array}$ & $\begin{array}{l}2 \% \text { wyborców } \\
\text { zarejestrowa- } \\
\text { nych w jednostce } \\
\text { lokalnej Republiki } \\
\text { Tatarstanu, nie } \\
\text { mniej niż } 25 \text { osób }\end{array}$ \\
\hline $\begin{array}{l}\text { Okres zbierania } \\
\text { podpisów pod } \\
\text { referendum oby- } \\
\text { watelskim }\end{array}$ & $45 \mathrm{dni}$ & - & $30 \mathrm{dni}$ & $30 \mathrm{dni}$ \\
\hline $\begin{array}{l}\text { Organ odpowie- } \\
\text { dzialny za organi- } \\
\text { zację referendum }\end{array}$ & $\begin{array}{l}\text { Centralna Komisja } \\
\text { Wyborcza }\end{array}$ & $\begin{array}{l}\text { Centralna Komi- } \\
\text { sja Wyborcza }\end{array}$ & $\begin{array}{l}\text { Centralna Komisja } \\
\text { Wyborcza Republi- } \\
\text { ki Tatarstanu }\end{array}$ & $\begin{array}{l}\text { Lokalna Komisja } \\
\text { Wyborcza }\end{array}$ \\
\hline
\end{tabular}

RFR - Federalna ustawa konstytucyjna O referendum w Federacji Rosyjskiej (RFR) z 11 czerwca 2004 roku; PGP - Ustawa federalna O podstawowych gwarancjach praw wyborczych oraz prawie do udziału $w$ referendum obywateli Federacji Rosyjskiej z 12 czerwca 2002 roku; RRT - Ustawa O referendum $w$ Republice Tatarstanu z 9 sierpnia 2003 roku; RL - Ustawa O referendum lokalnym $w$ Republice Tatarstanu z 23 marca 2004 roku.

Źródło: Opracowanie własne na podstawie wyżej wymienionych ustaw Federacji Rosyjskiej i Republiki Tatarstanu. 


\section{Referendum w Republice Tatarstanu w wymiarze praktycznym}

W Republice Tatarstanu przeprowadzono trzykrotnie referendum, w tym jedno referendum zorganizowano na obszarze republiki (referendum niepodległościowe w dniu 21 marca 1992 roku), natomiast dwa pozostałe odbyły się tylko w ograniczonym zakresie w ramach referendów ogólnofederalnych (referendum z 25 kwietnia 1993 roku oraz referendum konstytucyjne z 12 grudnia 1993 roku $)^{13}$.

Na referendum z 21 marca 1992 roku należy spojrzeć przez pryzmat nieustannej walki Tatarów nadwołżańskich o uzyskanie praw politycznych. Tatarzy nie mogli się posługiwać językiem tatarskim, a gospodarka Tatarstanu miała jedynie charakter ekstensywny $^{14}$. Dlatego wykorzystując sytuację geopolityczną ${ }^{15}$, w dniu 30 sierpnia 1990 roku 241 deputowanych spośród 242 obecnych na posiedzeniu Rady Najwyższej Tatarskiej Autonomicznej Socjalistycznej Republiki Radzieckiej zagłosowało za suwerennością re-

13 Do wykazu referendów przeprowadzonych w Tatarstanie można jeszcze zaliczyć głosowanie z 17 marca 1991 roku. Należy jednak zaznaczyć, że powyższe referendum odbyło się w ramach Związku Radzieckiego i wpłynęło na proces fragmentaryzacji, rozpadu i upadku państwa. Intencje Michaiła Gorbaczowa jako głównego inicjatora referendum były całkowicie odmienne, ponieważ dążył on do zachowania jedności państwa w nowej strukturze. Obywatele ZSRR odpowiadali na pytanie: „Czy uważasz za niezbędne zachowanie Związku Socjalistycznych Republik Radzieckich jako odnowionej federacji równoprawnych suwerennych republik, w których prawa człowieka i wolność każdej narodowości będzie w pełni zagwarantowana?". Tymczasem sześć podmiotów związkowych wykorzystało referendum do realizacji własnych dążeń niepodległościowych (Armenia, Estonia, Gruzja, Litwa, Łotwa, Mołdawia), w pięciu przypadkach dokonano modyfikacji pytania referendalnego lub do pytania referendalnego dodano drugie pytanie (Kazachstan, Kirgizja, Rosja, Ukraina i Uzbekistan), jedynie w czterech republikach referendum przeprowadzono w niezmienionej formule (Azerbejdżan, Białoruś, Tadżykistan i Turkmenistan). H.E. Brady, C.S. Kaplan, Eastern Europe and the Former Soviet Union, [w:] Referendums around the World. The Growing Use of Direct Democracy, eds D. Butler, A. Ranney, Washington 1994, s. 190-191, 193-194. Za zachowaniem ZSRR zagłosowało 87,52\% mieszkańców Tatarstanu (przy średniej 71,34\% dla Rosji). Frekwencja wyniosła 77,07\% uprawnionych do głosowania.

14 Tylko 2\% wartości produktów i towarów wytwarzanych w Republice Tatarstanu pozostawało na miejscu, a pozostałe $98 \%$ było eksportowane na wewnętrzny rynek ZSRR i Rosyjskiej Federacyjnej Socjalistycznej Republiki Radzieckiej (RFSRR). Tatarstan był znaczącym producentem kauczuku butylowego (około 75\% produkcji radzieckiej), materiałów fotograficznych i filmowych (połowa produkcji radzieckiej), polietylenu (około 25\%) i opon samochodowych (15\%), a dodatkowo istotnym dostawcą ropy naftowej i produktów rolnych. Ponadto w Tatarstanie zlokalizowano fabrykę samochodów KAMAZ. И. Тагиров, Татарстан: Веки истории XX век-начало ХХІ века, Каzań 2016, s. 195.

15 Należy podkreślić, że ogłoszenie Deklaracji suwerenności w Tatarstanie wpisało się w cykl przyjmowania aktów niezależności przez poszczególne podmioty wchodzące w skład Związku Radzieckiego i RFSRR. Tatarstan należał do jednego z pierwszych podmiotów RFSRR, które przyjęły deklarację suwerenności. Został wyprzedzony jedynie przez Osetię Północną (20 lipca 1990 roku), Republikę Karelii (9 sierpnia 1990 roku), Republikę Chakasji (15 sierpnia 1990 roku) oraz Republikę Komi (29 sierpnia 1990 roku). Proces ten trwał przez cały rok, aż do 2 lipca 1991 roku, gdy suwerenność ogłosiła Republika Adygei. В.В. Михайлов, Республика Татарстан: Демократия или Суверенитет?, Moskwa 2004, s. 106. 
publiki ${ }^{16}$. Jednak przyjęcie samego aktu suwerenności nie oznaczało automatycznie uzyskania całkowitej niezależności republiki, a jedynie rozpoczęcie długotrwałego procesu działań na rzecz zmiany statusu Tatarstanu. Kluczowe w tym zakresie było stanowisko władz Rosji, które ewoluowało od początkowej aprobaty dla dążeń niepodległościowych Tatarów, przez poszukiwanie rozwiązania kompromisowego, a skończywszy na zanegowaniu niezależności i odrębności terytorialno-ustrojowej Tatarstanu oraz pozostałych podmiotów wchodzących w skład Federacji Rosyjskiej. Miało to ścisły związek z rywalizacją polityczną wśród elit politycznych ZSRR i RFSRR. Borys Jelcyn, dążąc do zdobycia i umocnienia swojej władzy, wykorzystał lokalne nastroje społeczne i postawy separatystyczne, aby wraz z konsolidacją zdobytej władzy rozpocząć realizację polityki centralizacji państwa. W dniu 12 czerwca 1991 roku odbyły się wybory na stanowisko Prezydenta RFSRR, które zwyciężył wspomniany Jelcyn. Tego samego dnia przeprowadzono wybory na stanowisko Prezydenta Tatarstanu. Na urząd wybrano Mintimera Shaimiyeva, który uzyskał poparcie 70,6\% osób uczestniczących w głosowaniu.

W dniach 12-14 sierpnia 1991 roku odbyły się negocjacje dwustronne w sprawie uregulowania statusu republiki ${ }^{17}$. Pomimo rozbieżności w dniu 15 sierpnia 1991 roku podpisano protokół, który miał stanowić punkt wyjścia do dalszych konsultacji. W dokumencie wyrażono potrzebę zbudowania relacji pomiędzy stronami na podstawie zachowania odrębności historycznych, ekonomicznych i kulturowych. Podpisanie porozumienia przez Prezydentów RFSRR i RT zostało zaplanowane na 19 sierpnia 1991 roku, jednak destabilizacja państwa w wyniku puczu Janajewa wstrzymała proces negocjacji. W związku z dynamiczną sytuacją wewnętrzną i obawą, że wojska z garnizonu kazańskiego zostaną wykorzystane do przejęcia władzy w republice, Rada Najwyższa Republiki Tatarstanu przyjęła 21 lutego 1992 roku uchwałę nr 437-XII o przeprowadzeniu referendum niepodległościowego $\mathrm{w}$ dniu 21 marca $1992 \mathrm{roku}^{18}$. W uchwale ustalono treść pytania referendalnego: „Czy zgadzasz się, aby Republika Tatarstanu została państwem niepodległym, podmiotem prawa międzynarodowego, który buduje relacje z Federacją Rosyjską i pozostałymi republikami (państwami) za zasadach równości?”. Na pytanie można było odpowiedzieć pozytywnie lub negatywnie. Jednocześnie zakazano głosowania osobom bez stałego zameldowania w Tatarstanie. Wynik referendum miał być roz-

16 И. Тагиров, ор. cit., s. 204. W Deklaracji suwerenności powołano się na prawo wszystkich narodów do samostanowienia, w związku z powyższym przyjęto prawo Tatarów do suwerenności w ramach Republiki Tatarstanu. Ponadto zdecydowano, że bogactwa naturalne przynależą do narodu. Wprowadzono równorzędność języka tatarskiego i rosyjskiego oraz zapowiedziano przyjęcie konstytucji. Do czasu jej przyjęcia w RT obowiązują prawa Republiki, RFSRR i ZSRR, jeśli nie są sprzeczne z Deklaracją suwerenności. Ф.Х. Мухаметшин, Республика Татарстан: от референдума до договора, Kazań 1995, s. 144-145.

17 Warto podkreślić, że były to pierwsze rozmowy obu stron na zasadach partnerskich od 1552 roku, kiedy Iwan Groźny, car Rosji, zdobył i włączył chanat kazański w skład Rosji.

18 W odpowiedzi na uchwałę Rady Najwyższej RT, Sąd Konstytucyjny Federacji Rosyjskiej wydał w dniu 13 marca 1992 roku postanowienie, w którym stwierdził przekroczenie kompetencji przez Radę Najwyższą w zakresie ogłoszenia referendum niepodległościowego. B.В. Комарова, Референдумный Проиесс в Российской Федерации, Moskwa 2004, s. 45. 
patrzony w całości bez podziału na poszczególne części republiki i miał mieć charakter ostateczny i obligatoryjny. Po krótkotrwałej, ale burzliwej kampanii wyborczej, w której Rosjanie oskarżali Tatarów o separatyzm i dążenie do rozbicia jedności państwa, a Tatarzy Rosjan o łamanie prawa narodów do samostanowienia, przeprowadzono głosowanie, w którym udział wzięło 82\% uprawnionych do głosowania (2 132351 osób), na pytanie referendalne pozytywnie odpowiedziało 61,39\% uczestniczących w głosowaniu (130 956 wyborców), natomiast negatywnie 37,26\% (794 444). Ponadto 1,35\% osób biorących udział w referendum oddało głosy nieważne (28 851 wyborców) (patrz tabela 3).

Tabela 3. Wyniki referendum niepodległościowego w Tatarstanie z dnia 21 marca 1992 roku

\begin{tabular}{|c|c|c|c|c|c|c|}
\hline$\times$ & $\begin{array}{c}\text { obywate- } \\
\text { li, którzy } \\
\text { byli } \\
\text { za } \\
\text { (w mln) }\end{array}$ & $\begin{array}{l}\text { obywate- } \\
\text { li, którzy } \\
\text { byli za } \\
\text { (w \%) }\end{array}$ & $\begin{array}{l}\text { obywate- } \\
\text { li, którzy } \\
\text { byli } \\
\text { przeciw } \\
\text { (w mln) }\end{array}$ & $\begin{array}{l}\text { obywate- } \\
\text { li, którzy } \\
\text { byli } \\
\text { przeciw } \\
(\mathrm{w} \%)\end{array}$ & $\begin{array}{c}\text { głosów } \\
\text { nieważ- } \\
\text { nych } \\
\text { (w mln) }\end{array}$ & $\begin{array}{c}\text { głosów } \\
\text { nieważ- } \\
\text { nych } \\
(\mathrm{w} \%)\end{array}$ \\
\hline $\begin{array}{l}\text { Czy zgadzasz się, aby Re- } \\
\text { publika Tatarstanu została } \\
\text { państwem niepodległym, } \\
\text { podmiotem prawa międzyna- } \\
\text { rodowego, który buduje relacje } \\
\text { z Federacją Rosyjską i pozosta- } \\
\text { łymi republikami (państwami) } \\
\text { za zasadach równości? }\end{array}$ & 1309056 & 61,39 & 794444 & 37,26 & 28851 & 1,35 \\
\hline \multicolumn{7}{|c|}{ Liczba obywateli uprawnionych do udziału w referendum: 2600297} \\
\hline \multicolumn{7}{|c|}{ Liczba obywateli, którzy wzięli udział w referendum: 2132351} \\
\hline \multicolumn{7}{|c|}{ Frekwencja w referendum (w \%): 82,00 } \\
\hline
\end{tabular}

Źródło: Obwieszczenie Centralnej Komisji Referendalnej Republiki Tatarstanu z 25 marca 1992 roku, za: Р. Юныс, Татарстан Референдумы, Kazań 2000, s. 145.

Wynik referendum w dużym stopniu odzwierciedlał strukturę narodowościową Tatarstanu ${ }^{19}$. Ponad połowę ludności RT stanowią Tatarzy, natomiast blisko $40 \%$ mieszkańców to Rosjanie. Za niepodległością Tatarstanu w zdecydowanej większości opowiedzieli się Tatarzy wraz z pozostałymi narodowościami i grupami etnicznymi zamieszkującymi RT, natomiast przeciwko niezależności republiki zagłosowali przede wszystkim Rosjanie.

W największych miastach RT najliczniejszą narodowością są Rosjanie i znalazło to odzwierciedlenie w wyniku głosowania. W Kazaniu (stolica i jednocześnie najwięk-

19 W RT zamieszkują ponad 173 grupy etniczne, jednak za najliczniejsze należy uznać narodowości, których liczba przekracza 10 tysięcy osób. Wśród nich znajdują się: Tatarzy, Rosjanie, Czuwasze, Udmurci, Mordwini, Maryjczycy, Ukraińcy i Baszkirzy. Najliczniejsi są Tatarzy, których liczbę szacuje się na ponad 2 miliony mieszkańców ( $53,2 \%$ całej populacji RT), następnie Rosjanie (ponad 1,5 mln osób, 39,7\% całości) i Czuwasze (116 200 osób, tj. 3,1\% obywateli RT). W 1997 roku liczba ludności RT przekroczyła 3,77 mln osób. S. Chazbijewicz, Tatarstan. Kształtowanie się nowoczesnego narodu i państwa, Olsztyn 2016, s. 20-21. 
sze miasto Tatarstanu, ponad 1,2 mln mieszkańców), Bugulmie, Czystopolu, Jełabudze, Leninogorsku, Zielonodolsku Rosjanie stanowią najliczniejszą narodowość wśród mieszkańców i w miastach tych przeciwko niezależności Tatarstanu opowiedziała się większość głosujących. Inaczej wyglądała sytuacja w mieście Nabieryżnyje Czełny (drugie miasto pod względem liczby ludności, pół miliona mieszkańców), w którym Rosjanie są najliczniejszym narodem, ale niestanowiącym większości. Głosy Tatarów oraz pozostałych mieszkańców zaliczanych do innych narodowości, a także części samych Rosjan przeważyły na rzecz niepodległości Tatarstanu. W miastach z przewagą ludności tatarskiej: Aznakajewie, Almietjewsku, Niżniekamsku, za niepodległością republiki zagłosowała większość mieszkańców (patrz tabela 4).

Tabela 4. Wyniki referendum niepodległościowego w Tatarstanie z dnia 21 marca 1992 roku według kryterium miast i struktury narodowościowej

\begin{tabular}{|l|c|c|c|c|c|}
\hline $\begin{array}{c}\text { Miasto } \\
\text { Nazwa polska } \\
\text { (tatarska) }\end{array}$ & $\begin{array}{c}\text { Liczba } \\
\text { Tatarów } \\
\text { (w \%) }\end{array}$ & $\begin{array}{c}\text { Liczba } \\
\text { Rosjan } \\
(\mathrm{w} \%)\end{array}$ & $\begin{array}{c}\text { Frekwencja } \\
(\mathrm{w} \%)\end{array}$ & $\begin{array}{c}\text { Liczba obywateli, } \\
\text { którzy odpowie- } \\
\text { dzieli za (w \%) }\end{array}$ & $\begin{array}{c}\text { Liczba obywateli, } \\
\text { którzy odpowie- } \\
\text { dzieli nie (w \%) }\end{array}$ \\
\hline $\begin{array}{l}\text { Almietjewsk } \\
\text { (Elmet) }\end{array}$ & 50,4 & 42,9 & 81,8 & 71,4 & 27,8 \\
\hline $\begin{array}{l}\text { Aznakajewo } \\
\text { (Aznakaj) }\end{array}$ & 85,4 & 11,9 & 95,3 & 95,8 & 4,0 \\
\hline $\begin{array}{l}\text { Bugulma } \\
\text { (Begelma) }\end{array}$ & 29,1 & 63,0 & 75,6 & 32,5 & 66,0 \\
\hline Czystopol (Czystaj) & 30,2 & 65,8 & 78,4 & 38,2 & 60,8 \\
\hline Jełabuga (Alabuga) & 34,3 & 58,7 & 73,3 & 43,6 & 55,2 \\
\hline $\begin{array}{l}\text { Kazań } \\
\text { (Qazan) }\end{array}$ & 40,5 & 54,7 & 71,9 & 46,8 & 51,2 \\
\hline $\begin{array}{l}\text { Leninogorsk } \\
\text { (Leninogorsk) }\end{array}$ & 39,4 & 44,9 & 72,6 & 50,3 & 48,4 \\
\hline $\begin{array}{l}\text { Nabieryżnyje } \\
\text { Czełny } \\
\text { (Yar Calli) }\end{array}$ & 40,6 & 48,7 & 75,8 & 60,8 & 44,3 \\
\hline $\begin{array}{l}\text { Niżniekamsk } \\
\text { (Tuban Qama) }\end{array}$ & 46,5 & 46,1 & 75,7 & 54,3 & 52,5 \\
\hline $\begin{array}{l}\text { Zainsk } \\
\text { (Zey) }\end{array}$ & 48,7 & 46,7 & 74,3 & 46,5 & 55,1 \\
\hline $\begin{array}{l}\text { Zielenodolsk } \\
\text { (Jaszel Uzen) }\end{array}$ & 29,1 & 67,0 & 77,2 & 43,5 & \\
\hline
\end{tabular}

Źródło: Obwieszczenie Centralnej Komisji Referendalnej Republiki Tatarstanu z 25 marca 1992 roku, za: Р. Юныс, op. cit., s. 150.

Zależność między strukturą narodowościową a wynikami głosowania w referendum w większym stopniu można wykazać w przypadku rejonów ${ }^{20}$. Spośród 43 rejonów, w 34 najliczniejszą grupą narodowościową są Tatarzy i we wszystkich tych rejo-

20 Republika Tatarstanu jest podzielona na 43 rejony administracyjne. Ibidem, s. 20. 
nach mieszkańcy opowiedzieli się za niepodległością, natomiast w dziewięciu rejonach (aleksiejewskim, jełabuskim, łaiszewskim, niżniekamskim, nowoszeszmińskim, spaskim, tietiuskim, wierchnieusłońskim, zielenodolskim) Rosjanie stanowią większość, ale tylko $\mathrm{w}$ pięciu $\mathrm{z}$ nich wynik głosowania był przeciwny niepodległości. Ponadto w rejonach, w których dominowali Tatarzy, frekwencja wyborcza była wyższa w stosunku do rejonów zamieszkiwanych przez Rosjan, co może świadczyć o większej determinacji Tatarów i ich dążeniu do niezależności republiki (patrz tabela 5).

Tabela 5. Wyniki referendum niepodległościowego w Tatarstanie z dnia 21 marca 1992 roku według kryterium rejonów administracyjnych i struktury narodowościowej

\begin{tabular}{|c|c|c|c|c|c|}
\hline $\begin{array}{c}\text { Rejon } \\
\text { Nazwa polska } \\
\text { (tatarska) }\end{array}$ & $\begin{array}{l}\text { Liczba } \\
\text { Tatarów } \\
(\mathrm{w} \%)\end{array}$ & $\begin{array}{l}\text { Liczba } \\
\text { Rosjan } \\
(\mathrm{w} \%)\end{array}$ & $\begin{array}{l}\text { Frekwencja } \\
\qquad(\mathrm{w} \%)\end{array}$ & $\begin{array}{c}\text { Liczba } \\
\text { obywateli, którzy } \\
\text { odpowiedzieli za } \\
(\mathrm{w} \%)\end{array}$ & $\begin{array}{c}\text { Liczba } \\
\text { obywateli, którzy } \\
\text { odpowiedzieli nie } \\
(\mathrm{w} \%)\end{array}$ \\
\hline $\begin{array}{l}\text { Agryski } \\
\text { (Egerże rayoni) }\end{array}$ & 59,5 & 25,0 & 85,2 & 74,9 & 23,4 \\
\hline $\begin{array}{l}\text { Aksubajewski } \\
\text { (Aqsubay rayoni) }\end{array}$ & 38,2 & 16,2 & 96,0 & 62,2 & 36,6 \\
\hline $\begin{array}{l}\text { Aktanyski } \\
\text { (Aktanysh rayoni) }\end{array}$ & 96,4 & 0,6 & 98,3 & 99,6 & 0,3 \\
\hline $\begin{array}{l}\text { Aleksiejewski } \\
\text { (Alekseyevsk rayoni) }\end{array}$ & 28,2 & 59,9 & 96,5 & 51,0 & 48,2 \\
\hline $\begin{array}{l}\text { Alkiejewski } \\
\text { (Elki rayoni) }\end{array}$ & 61,7 & 16,5 & 98,4 & 85,8 & 12,6 \\
\hline $\begin{array}{l}\text { Almietjewski } \\
\text { (Elmet rayoni) }\end{array}$ & 54,6 & 33,3 & 96,8 & 74,0 & 25,0 \\
\hline $\begin{array}{l}\text { Antiński } \\
\text { (Etne rayoni) }\end{array}$ & 95,1 & 4,0 & 99,3 & 99,6 & 0,1 \\
\hline $\begin{array}{l}\text { Apastowski } \\
\text { (Apas rayoni) }\end{array}$ & 79,1 & 16,0 & 99,3 & 95,8 & 4,0 \\
\hline $\begin{array}{l}\text { Arski } \\
\text { (Arca rayoni) }\end{array}$ & 92,5 & 6,4 & 99,7 & 95,3 & 4,3 \\
\hline $\begin{array}{l}\text { Aznajewski } \\
\text { (Aznaqay rayoni) }\end{array}$ & 81,2 & 15,3 & 97,8 & 91,4 & 8,2 \\
\hline $\begin{array}{l}\text { Bałtasiński } \\
\text { (Baltac rayoni) }\end{array}$ & 84,3 & 1,2 & 99,7 & 95,0 & 3,0 \\
\hline $\begin{array}{l}\text { Bawliński } \\
\text { (Bayli rayoni) }\end{array}$ & 66,3 & 21,2 & 92,8 & 76,3 & 22,9 \\
\hline $\begin{array}{l}\text { Bugulmiński } \\
\text { (Begelma rayoni) }\end{array}$ & 44,9 & 42,5 & 97,0 & 54,3 & 44,6 \\
\hline $\begin{array}{l}\text { Buiński } \\
\text { (Bya rayoni) }\end{array}$ & 62,3 & 15,0 & 96,6 & 79,8 & 18,4 \\
\hline $\begin{array}{l}\text { Czeriemszański } \\
\text { (Czyrmeshen rayoni) }\end{array}$ & 52,1 & 18,9 & 98,0 & 75,9 & 22,7 \\
\hline $\begin{array}{l}\text { Czystopolski } \\
\text { (Czystaj rayoni) }\end{array}$ & 57,0 & 36,1 & 96,1 & 67,2 & 31,6 \\
\hline
\end{tabular}


Pobrane z czasopisma Wschód Europy http://journals.umcs.pl/we

Data: 26/04/2023 16:39:31

\begin{tabular}{|c|c|c|c|c|c|}
\hline $\begin{array}{c}\text { Rejon } \\
\text { Nazwa polska } \\
\text { (tatarska) }\end{array}$ & $\begin{array}{l}\text { Liczba } \\
\text { Tatarów } \\
(\mathrm{w} \%)\end{array}$ & $\begin{array}{l}\text { Liczba } \\
\text { Rosjan } \\
(w \%)\end{array}$ & $\begin{array}{l}\text { Frekwencja } \\
\qquad(\mathrm{w} \%)\end{array}$ & $\begin{array}{c}\text { Liczba } \\
\text { obywateli, którzy } \\
\text { odpowiedzieli za } \\
\text { (w \%) }\end{array}$ & $\begin{array}{c}\text { Liczba } \\
\text { obywateli, którzy } \\
\text { odpowiedzieli nie } \\
(\mathrm{w} \%)\end{array}$ \\
\hline $\begin{array}{l}\text { Drożżański } \\
\text { (Czuprele rayoni) }\end{array}$ & 58,4 & 0,9 & 97,1 & 77,8 & 20,3 \\
\hline $\begin{array}{l}\text { Jełabuski } \\
\text { (Alabuga rayoni) }\end{array}$ & 37,3 & 56,2 & 96,9 & 44,1 & 55,1 \\
\hline $\begin{array}{l}\text { Jutaziński } \\
\text { (Jutazy rayoni) }\end{array}$ & 62,6 & 29,4 & 94,3 & 82,2 & 16,6 \\
\hline $\begin{array}{l}\text { Kajbycki } \\
\text { (Kaybycz rayoni) }\end{array}$ & 79,1 & 16,0 & 98,5 & 76,3 & 22,6 \\
\hline $\begin{array}{l}\text { Kamsko-Ustiński } \\
\text { (Kama Tamagy } \\
\text { rayoni) }\end{array}$ & 49,3 & 48,1 & 95,0 & 62,4 & 36,7 \\
\hline $\begin{array}{l}\text { Kukmorski } \\
\text { (Kukmara rayoni) }\end{array}$ & 76,9 & 6,3 & 96,2 & 92,1 & 7,3 \\
\hline $\begin{array}{l}\text { Leninogorski } \\
\text { (Leninogorsk rayoni) }\end{array}$ & 73,1 & 13,2 & 98,0 & 85,2 & 14,1 \\
\hline $\begin{array}{l}\text { Łaiszewski } \\
\text { (Layis rayoni) }\end{array}$ & 36,9 & 60,7 & 91,5 & 46,8 & 52,2 \\
\hline $\begin{array}{l}\text { Mamadyski } \\
\text { (Mamadish Rayoni) }\end{array}$ & 75,2 & 24,2 & 96,2 & 80,9 & 18,1 \\
\hline $\begin{array}{l}\text { Miendielejewski } \\
\text { (Mendeleyevsk } \\
\text { rayoni) }\end{array}$ & 53,4 & 35,5 & 90,0 & 67,3 & 30,7 \\
\hline $\begin{array}{l}\text { Mienzieliński } \\
\text { (Minzele rayoni) }\end{array}$ & 60,4 & 35,2 & 92,3 & 79,9 & 19,1 \\
\hline $\begin{array}{l}\text { Myslumowski } \\
\text { (Móslim rayoni) }\end{array}$ & 89,1 & 7,5 & 99,6 & 98,3 & 1,4 \\
\hline $\begin{array}{l}\text { Niżniekamski } \\
\text { (Tuwen Kama rayoni) }\end{array}$ & 45,2 & 48,3 & 81,8 & 54,5 & 44,0 \\
\hline $\begin{array}{l}\text { Nowoszeszmiński } \\
\text { (Jana Czyshme } \\
\text { rayoni) }\end{array}$ & 43,1 & 51,6 & 97,3 & 58,2 & 41,2 \\
\hline $\begin{array}{l}\text { Nurłacki }{ }^{*} \\
\text { (Nurlat rayoni) }\end{array}$ & 44,2 & 25,6 & 94,1 & 64,4 & 34,7 \\
\hline $\begin{array}{l}\text { Piestrieczyński } \\
\text { (Pitrecz rayoni) }\end{array}$ & 54,2 & 44,2 & 93,4 & 59,6 & 39,4 \\
\hline $\begin{array}{l}\text { Rybno-Słobodzki } \\
\text { (Balyk Bystese rayoni) }\end{array}$ & 76,2 & 22,9 & 97,4 & 81,0 & 18,5 \\
\hline $\begin{array}{l}\text { Sabiński } \\
\text { (Sawa rayoni) }\end{array}$ & 92,8 & 6,2 & 98,4 & 98,4 & 1,3 \\
\hline $\begin{array}{l}\text { Sarmanowski } \\
\text { (Sarman rayoni) }\end{array}$ & 90,4 & 8,3 & 97,1 & 96,2 & 3,6 \\
\hline $\begin{array}{l}\text { Spaski } \\
\text { (Spas rayoni) }\end{array}$ & 29,7 & 67,0 & 92,2 & 42,5 & 56,6 \\
\hline $\begin{array}{l}\text { Tietiuski } \\
\text { (Tetesh rayoni) }\end{array}$ & 31,0 & 35,5 & 92,8 & 45,3 & 53,5 \\
\hline
\end{tabular}


Pobrane z czasopisma Wschód Europy http://journals.umcs.pl/we

Data: 26/04/2023 16:39:31

Instytucja referendum w Republice Tatarstanu (Federacja Rosyjska)

\begin{tabular}{|l|c|c|c|c|c|}
\hline \multicolumn{1}{|c|}{$\begin{array}{c}\text { Rejon } \\
\text { Nazwa polska } \\
\text { (tatarska) }\end{array}$} & $\begin{array}{c}\text { Liczba } \\
\text { Tatarów } \\
(\mathrm{w} \%)\end{array}$ & $\begin{array}{c}\text { Liczba } \\
\text { Rosjan } \\
(\mathrm{w} \%)\end{array}$ & $\begin{array}{c}\text { Frekwencja } \\
(\mathrm{w} \%)\end{array}$ & $\begin{array}{c}\text { Liczba } \\
\text { obywateli, którzy } \\
\text { odpowiedzieli za } \\
(\mathrm{w} \%)\end{array}$ & $\begin{array}{c}\text { Liczba } \\
\text { obywateli, którzy } \\
\text { odpowiedzieli nie } \\
(\mathrm{w} \%)\end{array}$ \\
\hline $\begin{array}{l}\text { Tiulaczyński } \\
\text { (Telecze rayoni) }\end{array}$ & 89,4 & 10,1 & 98,8 & 91,7 & 5,6 \\
\hline $\begin{array}{l}\text { Tukajewski } \\
\text { (Tukay rayoni) }\end{array}$ & 76,0 & 20,7 & 98,3 & 86,1 & 13,1 \\
\hline $\begin{array}{l}\text { Wierchnieusłoński } \\
\text { (Jugary Oslan rayoni) }\end{array}$ & 20,5 & 70,6 & 89,1 & 35,8 & 62,7 \\
\hline $\begin{array}{l}\text { Wysokogorski } \\
\text { (Biektay rayoni) }\end{array}$ & 56,4 & 41,4 & 93,9 & 69,3 & 29,8 \\
\hline $\begin{array}{l}\text { Zaiński } \\
\text { (Zey rayoni) }\end{array}$ & 75,5 & 21,9 & 98,2 & 78,0 & 21,4 \\
\hline $\begin{array}{l}\text { Zielenodolski } \\
\text { (Zelenodoi rayoni) }\end{array}$ & 43,5 & 51,4 & 89,2 & 58,1 & 40,7 \\
\hline
\end{tabular}

* Nazwa rejonu obowiązująca od 1997 roku. W dniu referendum jako rejon oktyborski.

Źródło: Obwieszczenie Centralnej Komisji Referendalnej Republiki Tatarstanu z 25 marca 1992 roku, za: P. Юныс, op. cit., s. 151.

Pomimo rozstrzygającego wyniku referendalnego był on interpretowany odmiennie przez obie strony sporu politycznego. Rosjanie podnosili zarzuty niekonstytucyjności referendum i niezgodności z prawem federalnym, natomiast Tatarzy podkreślali, że po referendum powstał nowy podmiot prawa międzynarodowego $\mathrm{z}$ własną polityką państwową. W celu wzmocnienia odrębności terytorialnej i administracyjnej Rada Najwyższa Republiki Tatarstanu w dniu 6 listopada 1992 roku przyjęła Konstytucję Republiki Tatarstanu. Już w art. 1 KRT nawiązano do Deklaracji suwerenności z 20 sierpnia 1990 roku oraz referendum niepodległościowego z 21 marca 1992 roku, stwierdzając, że: „Republika Tatarstanu jest suwerennym, demokratycznym państwem wyrażającym wolę i interesy wielonarodowej wspólnoty Republiki. Suwerenność i władza państwowa wywodzi się z ludu. Suwerenność państwowa jest niezbywalnym warunkiem istnienia Republiki Tatarstanu”. W art. 59 KRT przyjęto, że prawo RT obowiązuje na całym terytorium republiki pod warunkiem, że nie koliduje z prawem międzynarodowym. W art. 60 KRT zagwarantowano niepodzielność terytorialną republiki, a w art. 61 KRT przypomniano, że RT jest suwerennym podmiotem prawa międzynarodowego, stowarzyszonym z Federacją Rosyjską na podstawie umowy dwustronnej.

Począwszy od 1993 roku, Rosja zaczęła wywierać nacisk na RT w celu dokonania redefinicji polityki republiki, przez wykorzystanie elementów szantażu ekonomicznego (wyjątkowo mroźna zima w republice przyniosła wzrost cen oraz wzrost bezrobocia, co wpłynęło na pojawienie się negatywnych nastrojów społecznych w Tatarstanie). Powyższa polityka okazała się skuteczna, ponieważ przełożyła się na treść Traktatu zawartego pomiędzy Federacją Rosyjską i Republiką Tatarstanu O rozgraniczeniu obszarów działania $i$ wzajemnym współdziałaniu między organami władzy państwowej Federacji Rosyjskiej i organami władzy państwowej Republiki Tatarstanu, który został podpisany 
przez Prezydentów FR i RT w Moskwie w dniu 15 lutego 1994 roku. W dokumencie stwierdzono, że Tatarstan nie jest niepodległym państwem i podmiotem prawa międzynarodowego, a jedynie zachowano prawo do samookreślenia republiki. Ponadto zdefiniowano obszary działań pozostające $\mathrm{w}$ wyłącznych kompetencjach Republiki Tatarstanu (w art. 2 Traktatu wymieniono 15 obszarów), Federacji Rosyjskiej (w art. 4 Traktatu wyszczególniono 17 obszarów) oraz wspólnych (w art. 3 Traktatu wypunktowano 23 obszary). Ponadto $\mathrm{w}$ art. 8 Traktatu zapowiedziano utworzenie przedstawicielstw stron w Moskwie i Kazaniu. W obszarze działalności RT pozostawiono zasoby naturalne oraz możliwość prowadzenia własnej polityki gospodarczej.

Postanowienia traktatowe nie pozwalają na jednoznaczną ocenę. Z jednej strony, zważywszy na działania władz RT oraz Tatarów podejmowane w latach 1990-1993 na rzecz niezależności i niepodległości republiki ${ }^{21}$, należy stwierdzić, że zakończyły się one niepowodzeniem, ponieważ RT ostatecznie pozostała częścią Federacji Rosyjskiej. $\mathrm{Z}$ drugiej jednak strony, należy pamiętać, że dążenia do niepodległości republiki były możliwe tylko ze względu na sytuację wewnętrzną (dekompozycja i upadek ZSRR oraz

21 Listę referendów przeprowadzonych w Republice Tatarstanu uzupełniają dwa referenda zorganizowane w 1993 roku na terytorium całej Federacji Rosyjskiej. W dniu 25 kwietnia 1993 roku obywatele Federacji Rosyjskiej odpowiadali na cztery pytanie dotyczące ich oceny prezydentury Borysa Jelcyna oraz realizowanej przez Prezydenta FR i rząd polityki społeczno-gospodarczej, a dodatkowo czy opowiadają się za zorganizowaniem prezydenckich i parlamentarnych wyborów przedterminowych. Wynik referendum został uznany za wiążący i obowiązujący tylko w przypadku dwóch pierwszych pytań (poparcie Borysowi Jelcynowi jako Prezydentowi FR udzieliło 59,95\% uczestniczących w głosowaniu, natomiast politykę społeczno-gospodarczą poparło $54,35 \%$ głosujących), natomiast w dwóch pozostałych przypadkach poparcie społeczne nie przekroczyło 50\%. Russian Government Referendum I: Confidence in President Yeltsin, http://www.c2d.ch/detailed_display.php?/name=votes\&table=votes\&page=1\&parent_ id=8sublinkname=results\&id=39277, inf. 27 X 2016; Russian Government Referendum II: Confidence in the social and economic policies of President Yeltsin, http://www.c2d.ch/detailed_display.php?/ name $=$ votes\&table $=$ votes\&page $=1 \&$ parent $\_i d=8$ sublinkname $=$ results\&id $=39274$, inf. 27 X 2016; Russian Government Referendum III: Early presidential elections, http://www.c2d.ch/detailed_display. php?/name=votes\&table=votes\&page $=1 \&$ parent $\_i d=8$ sublinkname $=$ results\&id=39276, inf. 27 X 2016; Russian Governmental Referendum IV: Early congressional elections, http://www.c2d.ch/detailed display.php?/name=votes\&table=votes\&page $=1$ \&parent_id=8sublinkname $=$ results\&id=39275, inf. 27 X 2016. Należy jednak zaznaczyć, że było to związane z wyrokiem Sądu Konstytucyjnego FR z 21 kwietnia 1993 roku, który orzekł, że w przypadku tych pytań większość należy liczyć od liczby osób uprawnionych do głosowania, a nieuczestniczących w referendum. Frekwencja referendalna wyniosła $64,51 \%$ uprawnionych, tymczasem w Tatarstanie jedynie 22,57\% uprawnionych. В.В. Михайлов, op. cit., s. 180. Podobnie w przypadku referendum konstytucyjnego z 12 grudnia 1993 roku obywatele Federacji Rosyjskiej przyjęli nową Konstytucję (za opowiedziało się 58,43\% głosujących, frekwencja $54,80 \%$ uprawnionych). Tymczasem w Republice Tatarstanu do urn wyborczych przyszło jedynie 13,91\% uprawnionych. Za Konstytucją FR opowiedziało się 74,84\% głosujących. Итоги всенародного голососования по проекту Консституции Российской Федерации 12 декабря 1993 года, http:// cikrf.ru/banners/vib_arhiv/referendum/1993_ref_itogi.html, inf. 22 VIII 2017. Niską frekwencję wyborczą należy uznać jako wyraz dezaprobaty dla Konstytucji Federacji Rosyjskiej i polityki integracji, tym bardziej że Konstytucja Republiki Tatarstanu z 1992 roku odrzucała nadrzędność Konstytucji Federacji Rosyjskiej. В.В. Михайлов, op. cit., s. 406. 
okres walki o władzę w RFSRR). Wraz z konsolidacją i umocnieniem pozycji instytucjonalnej przez ośrodek prezydencki w Rosji rozpoczął się etap przywracania niezależnych republik do federacji (proces federalizacji państwa rosyjskiego ${ }^{22}$ ). Rosja dokonała tego na dwa sposoby: militarnie (Republika Czeczeńska) i politycznie (Republika Tatarstanu). Dodatkowo jako znaczące osiągnięcie należy uznać wywalczenie niezależności gospodarczej, co jeszcze przed 1990 rokiem było niemożliwe ${ }^{23}$.

Po 1994 roku w RT nie zorganizowano już żadnego referendum na poziomie republiki. Prymat uzyskało głosowanie pośrednie (wybory), a głosowanie bezpośrednie (referendum) stanowi jedynie element systemu prawnego nieznajdujący zastosowania w praktyce. Inaczej sytuacja wygląda w przypadku referendum lokalnego. Należy jednak zaznaczyć, że zakres problemowy głosowania lokalnego nie ma takiego znaczenia politycznego jak w przypadku referendum na poziomie republiki. W związku z powyższym jego rozstrzygnięcie nie może wpłynąć na integralność Federacji Rosyjskiej. W RT na poziomie lokalnym po 1990 roku zorganizowano 1430 referendów lokalnych ${ }^{24}$. Odbywały się one jedynie w sprawie dodatkowego opodatkowania obywateli na cele lokalne ${ }^{25}$.

Podsumowując, należy stwierdzić, że instytucja referendum stanowiła istotny element $\mathrm{w}$ walce politycznej o realizację prawa do samostanowienia narodu tatarskiego zamieszkującego w Republice Tatarstanu. Wykorzystanie referendum jest przykładem wzmocnienia dążeń władz RT na rzecz niepodległości oraz wywierania nacisku politycznego na Federację Rosyjską. W 1992 roku zorganizowano głosowanie referendalne, w którym większość obywateli potwierdziła aspiracje niepodległościowe i chęć uniezależnienia się od Rosji. Jednak rosyjska doktryna prawna zdecydowanie odrzuciła wynik referendum i uznała referendum jako niekonstytucyjne. Jednocześnie konsolidacja władzy prezydenckiej w Federacji Rosyjskiej po 1992 roku osłabiła aspiracje niepod-

22 Układ federacyjny pomiędzy władzami centralnymi Rosji oraz 87 podmiotami wchodzącymi w skład Federacji został podpisany w dniu 31 marca 1992 roku. Układ stał się integralną częścią Konstytucji FR. Należy podkreślić, że podpisania układu odmówiły Czeczenia i Tatarstan. J. Potulski, Idea i praktyka federalizmu w Rosji, Toruń 2004, s. 74.

23 Dodatkowo, w ocenie wydarzeń z lat 1990-1994 należy przypomnieć wypowiedzi, w których argumentowano, że w rzeczywistości Tatarstan nigdy nie chciał wychodzić z Rosji, a republika od początku dążyła do poprawy pozycji gospodarczej i finansowej. И. Тагиров, op. cit., s. 239.

24 Począwszy od 1993 roku, w Rosji zorganizowano 2626 referendów lokalnych (stan na 25 sierpnia $2017 \mathrm{roku}$ ). Oznacza to, że ponad połowę z nich (54\%) przeprowadzono w Republice Tatarstanu. Jednak w większości były to głosowania w okręgach wiejskich lub wiejskich o charakterze miejskim. Julian-Ivan Beriger wskazał Republikę Tatarstanu jako jedną z trzynastu republik FR, w których zorganizowano referenda w latach 1993-2016. J.-I. Beriger, Das Referendum in den Föderationssubjekten und Gemeinden des heutigen Russlands. Eine Analyse der normative Ausgestaltung und praktischen Anwendung, Baden-Baden 2016, s. 241. W Republice Tatarstanu zorganizowano najwięcej referendów lokalnych spośród podmiotów FR w latach 2003-2017. Zob. szerzej: W. Ziętara, Istytucja referendum w podmiotach Federacji Rosyjskiej. Wymiar prawny i praktyczny, [w:] Uwarunkowania demokracji bezpośredniej we wspótczesnej Europie, red. M. MusiałKarg, A. Stelmach, Poznań 2018, s. 91-107.

25 Referenda lokalne przeprowadzono w okresie od 6 marca 2016 roku do 16 kwietnia 2017 roku. http://www.tatarstan.vybory.izbirkom.ru/region/tatarstan, inf. 22 VIII 2017. 
ległościowe Tatarów i wpłynęła na rozpoczęcie negocjacji na temat przyszłego statusu RT. Zakończyły się one podpisaniem Traktatu w 1994 roku, w którym uregulowano stosunki pomiędzy Republiką Tatarstanu a Federacją Rosyjską. W wymiarze praktycznym przełożyło się to na możliwość prowadzenia własnej polityki gospodarczej przez Tatarstan, przy jednoczesnym potwierdzeniu członkostwa.

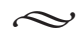

Streszczenie: Republika Tatarstanu jest jednym z 85 podmiotów Federacji Rosyjskiej wymienionych w Konstytucji Federacji Rosyjskiej (w tym Republiki Krymu i Sewastopola). Wobec innych podmiotów Republika Tatarstanu wyróżnia się liczbą zorganizowanych referendów. W Republice Tatarstanu w 1992 r. przeprowadzono referendum w celu określenia statusu republiki, a następnie ogłoszenia niepodległości. Jednak w związku ze zmianą polityki władz rosyjskich, polegającej na odrzuceniu wsparcia dla separatyzmów na rzecz konsolidacji państwa, Republika Tatarstanu nigdy nie została uznana za niezależny i suwerenny podmiot. Pomimo to Tatarom udało się znacząco zmienić swoją pozycję w celu zwiększenia niezależności finansowej i ekonomicznej. Było to możliwe, ponieważ wykorzystano głosowanie referendalne, a jego wynik legitymizował dążenia władz Tatarstanu. Ponadto warto podkreślić niezwykle częste praktykowane głosowania referendalne na szczeblu lokalnym. W związku z powyższym w artykule określono status prawny instytucji referendum w Republice Tatarstanu w świetle systemu prawnego Federacji Rosyjskiej oraz dokonano analizy zastosowania referendum na poziomie republiki i lokalnym na wybranych przykładach. Regulacje prawne są niemal identyczne z rozwiązaniami federalnymi. Po 1992 r. na poziomie republiki, instytucja referendum nie była już wykorzystywana, natomiast na szczeblu lokalnym była bardzo często stosowana i dotyczyła głównie dodatkowego opodatkowania obywateli na zadania lokalne.

Słowa kluczowe: referendum, demokracja bezpośrednia, Republika Tatarstanu, Federacja Rosyjska.

\section{Институт референдума в Республике Татарстан (Россия)}

Аннотация: Республика Татарстан является одним из 85 субъектов Российской Федерации, перечисленных в Конституции Российской Федерации (включая Республику Крым и Севастополь). По отношению к другим субъектам Республика Татарстан отличается количеством организованных референдумов. В 1992 году в Республике Татарстан был проведен референдум по определению статуса республики, после чего была провозглашена независимость. Однако, в связи с изменениями в политике российских властей, вовлекая отказ от поддержки сепаратизма в пользу консолидации государства, Республика Татарстан никогда не рассматривалась в качестве независимого и суверенного субъекта. Несмотря на это, татарам удалось существенно изменить свою позицию в целях повышения финансовой и экономической независимости. Это стало возможным потому, что голосование по референдуму было использовано, и результат узаконено стремления властей Татарстана. Кроме того, стоит подчеркнуть крайне частое голосование на референдуме, практикуемое на местном уровне. В связи с изложенным в статье определяется правовой статус института референдума в Республике Татарстан в све- 
Pobrane z czasopisma Wschód Europy http://journals.umcs.pl/we

Data: 26/04/2023 16:39:31

Instytucja referendum w Republice Tatarstanu (Federacja Rosyjska)

те правовой системы Российской Федерации и анализируется применение референдума на республиканском и местном уровнях на отдельных примерах. Правовые нормы практически идентичны федеральным решениям. После 1992 года на республиканском уровне институт референдума больше не использовался, а на местном уровне он очень часто использовался и касался в основном дополнительного налогообложения граждан для выполнения местных задач.

Ключевые слова: референдум, прямая демократия, Республика Татарстан, Российская Федерация.

\section{Institution of the referendum in the Republic of Tatarstan (Russian Federation)}

Abstract: The Republic of Tatarstan is one of the 85 entities of the Russian Federation listed in the Constitution of the Russian Federation (including the Republic of Crimea and Sevastopol). In relation to other entities, the Republic of Tatarstan stands out in the number of organized referendums. In the Republic of Tatarstan in 1992, a referendum was held to define the status of the republic and then declare the independence. However, as a result of the change in the policy of the Russian authorities consisting in the departure from supporting separatism for the consolidation of the state, the Republic of Tatarstan has never been recognized as an independent and sovereign entity. In spite of this, the Tartars have succeeded in fundamentally changing their position to increase financial and economic independence of the center. This was possible because a referendum was used and its outcome was referred to as the legitimacy of the actions of the Tatarstan authorities. In addition, it is worth emphasizing the extremely frequent use of referendum at the local level in the Republic of Tatarstan. In connection with the above, this article defines the legal status of the referendum in the Republic of Tatarstan in the light of the legal system of the Russian Federation and presents examples of the application of the referendum at the level of the republic and the local one. Legal regulations are largely identical to solutions at the federal level, the referendum was considered an example of direct rule of the people (article 3 of the Constitution of the Russian Federation from 1993 and article 3 of the Constitution of the Republic of Tatarstan from 1992). After 1992, at the level of the republic, the institution of the referendum was no longer used, and at the local level, although the institution of the referendum was very often used, it was mainly regarding the consent for additional taxation of citizens for local purposes.

Keywords: referendum, direct democracy, Republic of Tatarstan, Russian Federation.

\section{Bibliografia}

Konstytucja Federacji Rosyjskiej z 12 grudnia 1993 roku.

Konstytucja Republiki Tatarstanu z 6 listopada 1992 roku.

Konstytucja Ukrainy z 28 czerwca 1996 roku.

Deklaracja suwerenności Republiki Tatarstanu z 20 sierpnia 1990 roku.

Traktat 0 rozgraniczeniu obszarów działania i wzajemnym wspótdziałaniu między organami władzy państwowej Federacji Rosyjskiej i organami władzy państwowej Republiki Tatarstanu z 15 lutego 1994 roku. 
Federalna ustawa konstytucyjna Federacji Rosyjskiej z 21 marca 2017 roku N 6-FKZ 0 przyjęciu Republiki Krymu w skład Federacji Rosyjskiej i włączeniu w skład Federacji Rosyjskiej nowych podmiotów: Republiki Krymu i Sewastopola, miasta o znaczeniu federalnym.

Beriger J.-I., Das Referendum in den Föderationssubjekten und Gemeinden des heutigen Russlands. Eine Analyse der normative Ausgestaltung und praktischen Anwendung, Baden-Baden 2016.

Brady H. E., Kaplan C. S., Eastern Europe and the Former Soviet Union, [w:] Referendums around the World. The Growing Use of Direct Democracy, eds D. Butler, A. Ranney, Washington 1994.

Chazbijewicz S., Tatarstan. Kształtowanie się nowoczesnego narodu i państwa, Olsztyn 2016.

Potulski J., Idea i praktyka federalizmu w Rosji, Toruń 2004.

Zieliński E., System konstytucyjny Federacji Rosyjskiej, Warszawa 2005.

Ziętara W., Istytucja referendum w podmiotach Federacji Rosyjskiej. Wymiar prawny i praktyczny, [w:] Uwarunkowania demokracji bezpośredniej we współczesnej Europie, red. M. Musiat-Karg, A. Stelmach, Poznań 2018.

Russian Government Referendum I: Confidence in President Yeltsin, http://www.c2d.ch/detailed_display.php?/name=votes\&table=votes\&page $=1$ \&parent_id $=8$ sublinkname=results\&id $=39277$

Russian Government Referendum II: Confidence in the social and economic policies of President Yeltsin, http://www.c2d.ch/detailed_display.php?/name=votes\&table=votes\&page=1\&parent_id=8sublinkname=results\&id=39274

Russian Government Referendum III: Early presidential elections, http://www.c2d.ch/detailed_display. php?/name=votes\&table=votes\&page=1\&parent_id=8sublinkname=results\&id=39276

Russian Governmental Referendum IV: Early congressional elections, http://www.c2d.ch/detailed_dis-

play.php?/name=votes\&table=votes\&page=1\&parent_id=8sublinkname=results\&id=39275

http://www.tatarstan.vybory.izbirkom.ru/region/tatarstan

http://www.c2d.ch

Zakon Respubliki Tatarstan o vnesenii izmeneniy i dopolneniy v otdel'nyye stat'i Konstitutsii Respubliki Tatarstan, 12 marta 2004 goda, N 10-ZRT.

Federalnyy Konstitutsionnyy Zakon Rossiyskoy Federatsii o referendume Rossiyskoy Federatsii, 28 iyunya 2004 goda, N5-FKZ.

Federal'nyy zakon Rossiyskoy Federatsii ob osnovnykh garantiyakh izbiratel'nykh prav i prava na uchastiye v referendume grazhdan Rossiyskoy Federatsii, 12 iyunya 2002 goda, N 67-FZ.

Zakon Respubliki Tatarstan o referendume Respubliki Tatarstan, 9 avgusta 2003 goda, N 33-ZRT.

Zakon Respubliki Tatarstan o mestnom referendume Respubliki Tatarstan, 23 marta 2004 goda, N 23ZRT.

Komarova V. V., Referendumnyy Protsess v Rossiyskoy Federatsii, Moskva 2004.

Mikhaylov V. V., Respublika Tatarstan: Demokratiya ili Suverenitet?, Moskva 2004.

Mukhametshin F. Kh., Respublika Tatarstan: ot referenduma do dogovora, Kazan' 1995.

Tagirov I., Tatarstan: Veki istorii XX vek- nachalo XXI veka, Kazan' 2016.

Itogi vsenarodnogo golososovaniya po proyektu Konstitutsii Rossiyskoy Federatsii 12 dekabrya 1993 goda, http://cikrf.ru/banners/vib_arhiv/referendum/1993_ref_itogi.html 